Effects of Orarian Theca Cel Is on Granul osa Cel I Di fferent i at i on During Gonadot r opi n-I ndependent Fol I i cul ar Grouth i n Cat $\mathrm{t}$ l e

\begin{tabular}{|l|l|}
\hline 著者 & $\begin{array}{l}\text { Or i saka Makot o, M zut ani Tet suya, Taj i ma } \\
\text { Ki mi hi sa, Or i saka Sanae, Shukunam Ken- i chi , } \\
\text { M yambt o Kaor u, Kot suj i Fum kazu }\end{array}$ \\
\hline $\begin{array}{l}\text { j our nal or } \\
\text { publ i cat i on t i t l e }\end{array}$ & Mbl ecul ar Repr oduct i on and Devel opment \\
\hline vol une & 73 \\
\hline number & 6 \\
\hline page r ange & $737-744$ \\
\hline year & $2006-03$ \\
\hline URL & ht t p: //hdl . handl e. net /10098/1504 \\
\hline
\end{tabular}




\title{
Effects of Ovarian Theca Cells on Granulosa Cell Differentiation During Gonadotropin-Independent Follicular Growth in Cattle
}

\author{
MAKOTO ORISAKA, ${ }^{1}$ TETSUYA MIZUTANI, ${ }^{2,3}$ KIMIHISA TAJIMA, ${ }^{1}$ SANAE ORISAKA, ${ }^{1}$ \\ KEN-ICHI SHUKUNAMI, ${ }^{1}$ KAORU MIYAMOTO, ${ }^{2,3}$ AND FUMIKAZU KOTSU II ${ }^{1 *}$ \\ ${ }^{1}$ Department of Obstetrics and Gynecology, University of Fukui, Fukui, Japan \\ ${ }^{2}$ Department of Biochemistry, University of Fukui, Fukui, Japan \\ ${ }^{3}$ CREST, JST (Japan Science and Technology Agency), Japan
}

\begin{abstract}
We investigated the effects of theca cells or FSH on granulosa cell differentiation and steroid production during bovine early follicular growth, using a co-culture system in which granulosa and theca cells were cultured on opposite sides of a collagen membrane. Follicular cells were isolated from early antral follicles $(2-4 \mathrm{~mm})$ that were assumed to be in gonadotropin-independent phase and just before recruitment into a follicular wave. Granulosa cells were cultured under serum-free conditions with and without theca cells or recombinant human FSH to test their effects on granulosa cell differentiation. Messenger RNA levels for P450 aromatase (aromatase), P450

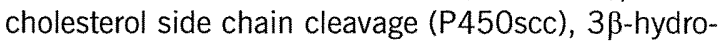

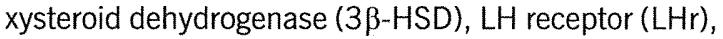
and steroidogenic acute regulatory protein (StAR) in granulosa cells were measured by real-time quantitative RT-PCR analysis. FSH enhanced aromatase mRNA expression in granulosa cells, but did not alter estradiol production. FSH also enhanced mRNA expression for P450scc, $\mathrm{LHr}$, and StAR in granulosa cells, resulting in an increase in progesterone production. In contrast, theca cells enhanced aromatase mRNA expression in granulosa cells resulting in an increase in estradiol production. Theca cells did not alter progesterone production and $\mathrm{mRNA}$ expression in

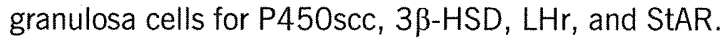
The results of the present study indicate that theca cells are involved in both rate-limiting steps in estrogen production, i.e., androgen substrate production and aromatase regulation, and that theca cell-derived factors regulate estradiol and progesterone production in a way that reflects steroidogenesis during the follicular phase of the estrous cycle.
\end{abstract}

Key Words: aromatase; estrogen; follicle; granulosa cells; theca cells

\section{INTRODUCTION}

Although it is true that ovarian follicular growth is under the endocrine control of pituitary gonadotropins, we also know now that early follicular growth is independent of gonadotropins and under the control of local autocrine/paracrine systems (Gougeon, 1996; Driancourt et al., 2000; McGee and Hsueh, 2000; Nilsson and Skinner, 2001; Richards, 2001; Vitt and Hsueh, 2001; Monget et al., 2002). Recently, bovine follicular development has been classified into three phases according to its dependency upon FSH and/or LH (Ginther et al., 1996; Webb et al., 1999). They are: (1) basal growth through primordial, primary, secondary, and preantral follicles is believed to be absolutely independent of gonadotropins, (2) growth of preantral and early antral follicles up to $4 \mathrm{~mm}$ in diameter is thought to be somewhat responsive to FSH, but independent of gonadotropins. Actually, bovine follicles can grow to this size even when gonadotropin secretion is suppressed by hypothalamic stalk transection (Awotwi et al., 1984) or by administration of a $\mathrm{GnRH}$ agonist (Campbell et al., 1995; Gong et al., 1996), and (3) antral follicular growth beyond $4 \mathrm{~mm}$ is considered to be critically dependent on gơnadotropins and includes recruitment (a cohort of follicles $4-5 \mathrm{~mm}$ in diameter emerges and begins to grow), selection (one follicle 8$9 \mathrm{~mm}$ in diameter develops from a wave of growing follicles and becomes the only follicle with ovulatory capacity), and ovulation.

A growing body of evidence indicates that steroidal and nonsteroidal factors produced by granulosa and theca cells influence differentiation and proliferation of both cell types on opposite sides of a basement membrane (Gougeon, 1996; Driancourt et al., 2000; McGee and Hsueh, 2000; Nilsson and Skinner, 2001; Richards, 2001; Vitt and Hsueh, 2001; Monget et al., 2002), which suggests the importance of granulosa-theca cell communication during folliculogenesis. To study the importance of the paracrine mechanisms between the theca

Grant sponsor: The Ministry of Education, Science, and Culture of Japan.

*Correspondence to: Fumikazu Kotsuji, Department of Obstetrics and Gynecology, University of Fukui, Shimoaiduki, Matsuoka, Fukui 9101193, Japan. E-mail: kotsujif@fmsrsa.fukui-med.ac.jp 
and granulosa cells, we have developed a novel in vitro co-culture system (Kotsuji et al., 1990). By culturing with granulosa cells and theca cells on opposite sides of a collagen membrane, this co-culture model is designed to mimic the in vivo ovarian cellular environment (Fig. 1). In our culture system, the co-cultured cells have similar morphological and functional characteristics as follicular cells do in vivo (Kotsuji et al., 1990; Kotsuji and Tominaga, 1994). Reflecting the observation mentioned above, we have shown that the granulosa cells continue their estradiol production in our culture system (Yada et al., 1999), though bovine granulosa cells rapidly luteinize and lose the ability to produce estradiol in most cell culture systems. Using our model, we have demonstrated that theca cells play important roles on proliferation (Kotsuji et al., 1990; Kotsuji and Tominaga, 1994), differentiation (Kotsuji et al., 1990; Kotsuji and Tominaga, 1994; Yada et al., 1999), and apoptosis (Tajima et al., 2002) of granulosa cells during follicular maturation.

Follicular development is characterized by proliferation and functional differentiation of granulosa and theca cells. In situ hybridization studies indicated that expression of mRNAs for the gonadotropin receptors (FSH receptor [FSHr] and $\mathrm{LH}$ receptor [LHr]), key steroidogenic enzymes (P450 aromatase [aromatase], P450 cholesterol side chain cleavage $[\mathrm{P} 450 \mathrm{scc}], 3 \beta$ hydroxysteroid dehydrogenase [3$\beta-\mathrm{HSD}])$, and steroidogenic acute regulatory protein (StAR) in granulosa cells is dependent on the stage of follicular development, and that granulosa cell differentiation is characterized by the expression of these genes (Bao and Garverick, 1998; Webb et al., 1999). Prior to follicular recruitment, granulosa cells from early antral follicles $(<4 \mathrm{~mm})$ expressed FSHr mRNA but not the genes of steroidogenic enzymes. Expression of mRNAs for aromatase and P450scc was first detected in granulosa cells in the majority of early recruited follicles $4-6 \mathrm{~mm}$ in diameter. Therefore, the recruitment seems to be closely associated with the initiation of mRNA expression for aromatase and P450scc in granulosa cells. Expression of LHr and 3 $\beta$-HSD mRNA in granulosa cells was first detected around the time of selection $(8-9 \mathrm{~mm}$ in diameter) of the dominant follicle, indicating that the selection is associated with initiation of mRNA expres-

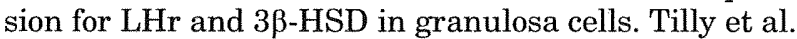
(1992) reported that spontaneous luteinization of the

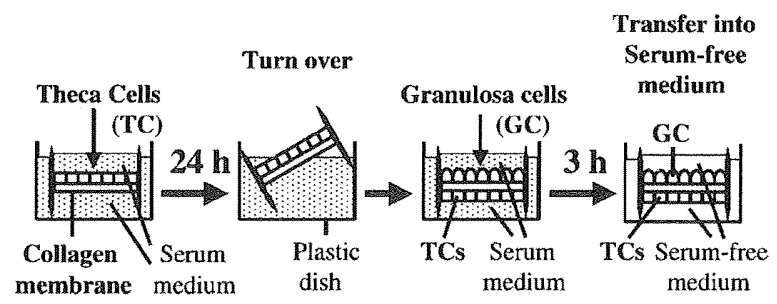

Fig. 1. Co-culture of granulosa and theca cells on a collagen membrane. granulosa cells after degeneration of the oocyte (i.e.,

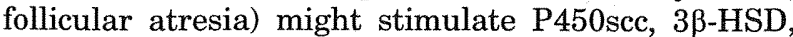
and StAR mRNA expression in granulosa cells in a similar way to the luteinization caused by the preovulatory LH surge. Thus, changes in gene expression are likely to be important to recruitment, selection, ovulation, and atresia in ovarian follicles.

In recent years, it has generally been accepted that the local autocrine/paracrine systems play a central role during the gonadotropin-independent follicular growth. Therefore, we hypothesize that theca cells may stimulate the differentiation of granulosa cells at the early stage of follicular development. In this study, in order to test this hypothesis, we investigated how theca cells control the differentiation of granulosa cells at early antral follicles using our in vitro co-culture system.

\section{MATERIALS AND METHODS}

\section{Preparations of Granulosa and Theca cells}

Monotocous species, such as cattle, horses, and primates, are particularly useful models for studying mechanisms of follicular recruitment, selection, and dominance (Ginther et al., 1996; Fortune et al., 2001). In the present study, bovine ovaries were collected from heifers at a local abattoir and were transported to the laboratory in ice-cold buffered salt solution. The stage of estrous cycle was determined morphologically, as previously described by Ireland et al. (1980) and only ovaries with a regressing corpus luteum were used for this study. Both granulosa and theca cells were collected from early antral follicles (2-4 $\mathrm{mm}$ in diameter) that were assumed to be in the gonadotropin-independent phase and in the recruitable state (i.e., just before recruitment into a follicular wave for further development) (Ginther et al., 1996; Bao and Garverick, 1998; Webb et al., 1999).

Follicular cells were prepared from the ovaries under sterile conditions as described previously (Kotsuji and Tominaga, 1994). Briefly, granulosa cells were harvested by aseptic needle aspiration from follicles and washed three times in a culture medium consisting of Waymouth MB 752/1 medium (Invitrogen Corp., Carlsbad, CA), Hanks solution (Nissui Pharmaceutical Co., Tokyo, Japan), and fetal calf serum (FCS; 6:3:1, $\mathrm{v}: \mathrm{v}: \mathrm{v})$ (Invitrogen) supplemented with streptomycin $(100 \mu \mathrm{g} / \mathrm{ml}$; Invitrogen) and penicillin $(100 \mathrm{U} / \mathrm{ml}$; Invitrogen). Washed cells were resuspended in culture medium, and cell viability was estimated at $30-42 \%$ by trypan blue exclusion.

For theca cell preparation, follicles with clear surfaces were cut into halves, and the theca interna layer was removed with fine forceps. Granulosa cells, together with a part of the theca cell layer, were removed by scraping with a scalpel under stereomicroscopy. The thin theca cell layer thus obtained was minced and then treated with a Hanks-Hepes buffer containing collagenase (2,150 U/ml, type 1; Sigma Chemical Co., St. Louis, MO), and DNase (100 U/ml; Sigma), $0.4 \%$ (v/v) bovine serum albumin (Sigma), and $0.2 \%(\mathrm{w} / \mathrm{v})$ glucose $(\mathrm{pH} 7.4)$. 
Cell dissociation was allowed to continue for $45 \mathrm{~min}$ at $37^{\circ} \mathrm{C}$ with continuous stirring at $800 \mathrm{rpm}$ and with $0.25 \%(\mathrm{w} / \mathrm{v})$ pancreatin (Sigma) in a Hanks-Hepes buffer for $7 \mathrm{~min}$. Dispersed cells were washed three times and cell viability was estimated at $90-95 \%$ by trypan blue exclusion test.

\section{Co-Culture of Granulosa and Theca cells on Collagen Membrane}

Co-culture of granulosa and theca cells on a collagen membrane was prepared as previously described (Kotsuji and Tominaga, 1994) with minor modifications (Fig. 1). The membrane (thickness, $70 \mu \mathrm{m}$; Koken Co., Tokyo, Japan) was made of type 1 collagen and had an area of $8 \mathrm{~cm}^{2}$. A supporting apparatus, to which a membrane was attached, was placed in a $6 \mathrm{~cm}$ plastic dish. Apical and basal chambers were separated, and materials less than $12.5 \mathrm{kDa}$ were permeable through the collagen membrane.

Theca cells $\left(5 \times 10^{5}\right.$ or $1 \times 10^{6}$ viable cells per dish) were seeded onto a type 1 collagen membrane immediately after preparation in $1.5 \mathrm{ml}$ culture medium consisting of Waymouth MB 752/1 medium, Hanks solution, and $10 \%$ FCS (6:3:1, v:v:v), supplemented with streptomycin $(100 \mu \mathrm{g} / \mathrm{ml})$ and penicillin $(100 \mathrm{U} / \mathrm{ml})$. To allow the theca cells to attach to the collagen membrane, cultures were maintained for $24 \mathrm{hr}$ in a humidified atmosphere of $5 \% \quad \mathrm{CO}_{2}$ and $95 \%$ air at $37^{\circ} \mathrm{C}$. The membrane was then turned over and freshly prepared granulosa cells $\left(1 \times 10^{6}\right.$ viable cells per dish) were seeded on the opposite side (co-cultured). Following an additional $3 \mathrm{hr}$ culture in a medium containing $10 \%$ FCS to facilitate the attachment of granulosa cells to the membrane, the medium was changed to serum-free Ham F-12 medium (Nissui) supplemented with insulin $(2 \mu \mathrm{g} / \mathrm{ml})$, transferrin $(10 \mu \mathrm{g} / \mathrm{ml})$, and testosterone $\left(10^{-8}\right.$ $\mathrm{mol} / \mathrm{L}$, as an aromatizing substrate) and the cells were cultured for up to $48 \mathrm{hr}$.

\section{Experimental Design}

To determine the effect of theca cells or FSH on granulosa cell differentiation, we prepared three groups. In GC group (as control), freshly prepared granulosa cells $\left(1 \times 10^{6}\right.$ viable cells per dish) alone were seeded on one side of a collagen membrane, and cultured for $3 \mathrm{hr}$ under serum supplemented conditions to allow granulosa cells attachment onto the membrane. The cells were then transferred into serum-free Ham F-12 supplemented with insulin, transferrin, and testosterone, and cultured for up to $48 \mathrm{hr}$. In GC+FSH group, granulosa cells $\left(1 \times 10^{6}\right.$ viable cells per dish) alone were cultured on one side of a membrane under serum supplemented conditions for $3 \mathrm{hr}$. The cells were then transferred into serum-free Ham F-12 supplemented with insulin, transferrin, and testosterone, and treated with increasing concentrations of recombinant human FSH (0.01-1 IU/ml; Gonal-F; Serono, Geneva, Switzerland) for $48 \mathrm{hr}$. In GC + TC group, granulosa cells were cultured together with theca cells $\left(5 \times 10^{5}\right.$ or $1 \times 10^{6}$ viable cells) as described above.
The medium was collected from the apical and basal chambers separately and stored at $-20^{\circ} \mathrm{C}$ for steroid assays. Cultured granulosa cells in each of the individual membranes were removed by trypsin treatment (1\% trypsin and $0.2 \%$ EDTA in a $0.01 \mathrm{M}$ phosphate buffer, $\mathrm{pH} 7.4$ ) at $37^{\circ} \mathrm{C}$ for $5 \mathrm{~min}$. Total cellular RNAs were extracted by the guanidium acid-isothiocyanatephenol-chlorform method using TRIzol (Invitrogen), quantified by measuring the absorbance at $260 \mathrm{~nm}$ and stored at $-80^{\circ} \mathrm{C}$, pending analysis.

\section{Steroid Assays}

Estradiol and progesterone were measured in the culture media from the granulosa cell side by a doubleantibody RIA $\left({ }^{125} \mathrm{I}\right)$. All samples were analyzed in the same assays, and the intra-assay coefficients of variation for estradiol and progesterone were 7.3 and $6.4 \%$, respectively. Our preliminary study showed that theca cells alone produced negligible amounts of progesterone ( $<5 \%$ of that by granulosa cells), and did not produce estradiol (data not shown). This suggests that granulosa cells are the primary source of these hormones under these experimental conditions.

\section{RT-PCR}

RT-PCR analyses for bovine aromatase, P450sec, $3 \beta$ HSD, LHr, StAR, and 36B4 were performed on total RNAs from cultured granulosa cells using specific primers. 36B 4 codes for acidic ribosomal phosphoprotein and is considered to be an efficient endogenous control gene, as previously described by Mazerbourg et al. (2001). 36B4 was measured to correct the differences in RNA concentration between samples. Bovine 36B4 genes were partially sequenced to design the specific primers presented in Table 1.

Our preliminary study showed that granulosa cells cultured with and without FSH or theca cells expressed negligible level of $17 \beta$-hydroxysteroid dehydrogenase, and did not express 17a-hydroxylase/17, 20-lyase mRNA (data not shown).

TABLE 1. Primers Used for Real-Time Quantitative RT-PCR

\section{$36 \mathrm{~B} 4$}

Forward primer GGC GAC CTG GAA GTC CAA CT Reverse primer GGA TCT GCT GCA TCT GCT TG Aromatase

Forward primer GCC CAT GGT GAC CAT CTG T Reverse primer CAC ATA GCC CAA GTC ATT GCA P450scc

Forward primer CTT CAT CCC ACT GCT GAA TCC Reverse primer GGT GAT GGA CTC AAA GGC AAA $3 \beta$-HSD

Forward primer GCC CAA CTC CTA CAG GGA GAT Reverse primer TTC AGA GCC CAC CCA TTA GCT

LH receptor

Forward primer TGG CTG GGA TTA TGA CTA TGG TT Reverse primer ATT TCC CGT GAT GGC TAG GAT A StAR

Forward primer CCC AGC AGA AGG GTG TCA TC Reverse primer TGC GAG AGG ACC TGG TTG AT 
In each case, RNAs were reverse transcribed in a final volume of $40 \mu \mathrm{l}$ solution containing $1 \times$ First-Strand Buffer ( $3 \mathrm{mM} \mathrm{MgCl}_{2}, 75 \mathrm{mM} \mathrm{KCl,} 50 \mathrm{mM}$ Tris-HCl, pH 8.3), $500 \mu \mathrm{M}$ each deoxynucleotide triphosphate (dNTP), $10 \mathrm{mM}$ dithiothreitol, $200 \mathrm{U}$ of SuperScript III RNase H free reverse transcriptase (Invitrogen), $200 \mathrm{ng}$ random hexamers, and $2 \mu \mathrm{g}$ total RNA. The target cDNAs of granulosa cells were amplified for 25 cycles (P450scc, $3 \beta$ HSD, 36B4) or 35 cycles (aromatase, LHr, StAR) $\left(94^{\circ} \mathrm{C}\right.$ for $20 \mathrm{sec}, 60^{\circ} \mathrm{C}$ for $30 \mathrm{sec}$, and $72^{\circ} \mathrm{C}$ for $60 \mathrm{sec}$ ), using dNTP $(0.2 \mathrm{mM})$ and $1.5 \mathrm{U}$ of TaKaRa Ex Taq (Takara Shuzo Co., Kyoto, Japan) in a thermal cycler. Aliquots of PCR products were electrophoresed on $2 \%$ agarose gels and visualized with ethidium bromide staining.

\section{Real-Time RT-PCR}

Real-time quantitative PCR analyses for bovine aromatase, P450scc, 3 $\beta$-HSD, LHr, and StAR were performed on total RNAs from cultured granulosa cells, using an ABI PRISM 7700 sequence detection system instrument and software (PE Applied Biosystems, Foster City, CA). The analyses were performed using specific primers presented in Table 1. Each transcript level of target genes (aromatase, P450sce, 33-HSD, LHr, and StAR) was normalized on the basis of the level of transcripts for the constitutive housekeeping gene product $36 \mathrm{~B} 4$.

In each case, RNAs were reverse transcribed in a final volume of $20 \mu \mathrm{l}$ solution containing $1 \times$ First-Strand Buffer (3 mM MgCl $2,75 \mathrm{mM} \mathrm{KCl}, 50 \mathrm{mM}$ Tris-HCl, pH 8.3), $500 \mu \mathrm{M}$ each dNTP, $10 \mathrm{mM}$ dithiothreitol, $100 \mathrm{U}$ of SuperScript II RNase $H$ reverse transcriptase (Invitrogen), $100 \mathrm{ng}$ random hexamers, and $1 \mu \mathrm{g}$ total RNA. Amplification reaction was then performed using the SYBR Green PCR Master Mix kit (PE Applied Biosystems). The thermal cycling conditions were comprised of an initial denaturation step at $95^{\circ} \mathrm{C}$ for $10 \mathrm{~min}$ and 40 cycles at $95^{\circ} \mathrm{C}$ for $15 \mathrm{sec}$, and $60^{\circ} \mathrm{C}$ for $1 \mathrm{~min}$. Levels of aromatase, P450scc, 3 $\beta-\mathrm{HSD}$, LHr, and StAR message were expressed as ratios to $36 \mathrm{~B} 4 \mathrm{mRNA}$ values.

\section{Statistical Analysis}

Each study was repeated three times on different days. Data are presented as the mean \pm SEM of the three experiments, each with three replicate culture dishes. ANOVA statistical analysis was performed. When a significant effect was detected $(P<0.05)$, Tukey-Kramer test was used for intergroup comparison. All statistical analysis was performed using a statistical analysis program (Stat View version 5.0; SAS Institute, Inc., Cary, NC).

\section{RESULTS}

\section{Granulosa Cell Proliferation}

To determine the effect of theca cells or FSH on granulosa cell proliferation, isolated granulosa cells were cultured with and without FSH or theca cells in serum-free medium for up to $48 \mathrm{hr}$, and granulosa cell numbers were determined with a hemacytometer.
There was no significant difference in the number of granulosa cells among GC, GC $+\mathrm{FSH}$, and $\mathrm{GC}+\mathrm{TC}$ groups (data not shown).

\section{Steroid Production by Granulosa Cells}

To determine the effect of theca cells or FSH on steroid production by granulosa cells, isolated granulosa cells were cultured with and without FSH or theca cells in serum-free medium for up to $48 \mathrm{hr}$, and estradiol and progesterone in the culture media were measured.

FSH stimulation caused a dose-related increase in progesterone production by granulosa cells during $24 \mathrm{hr}$ culture $(P<0.05)$ (Fig. 3), but it did not alter estradiol production even after $48 \mathrm{hr}$ culture (Fig. 2). In contrast, co-culturing with theca cells significantly increased estradiol production by granulosa cells after $24 \mathrm{hr}$ culture $(P<0.05)$ dependent on the theca cell number (Fig. 2), whereas it had no effect on progesterone production during $48 \mathrm{hr}$ culture (Fig. 3).

\section{Expression of Steroidogenic Enzymes, LH \\ Receptor, StAR in Cultured Granulosa Cells}

Granulosa cell differentiation is characterized by the induction of gene expression for the steroidogenic enzymes, LHr and StAR. To determine the effect of theca cells or FSH on granulosa cell differentiation, the mRNA levels for aromatase, P450scc, 3 $\beta$-HSD, LHr, and StAR in the cultured granulosa cells were measured by conventional RT-PCR (Fig. 4A) and real-time quantitative RT-PCR (Fig. 4B) assays. These data were normalized by the levels of internal control, $36 \mathrm{~B} 4$.

As shown in Figures 2 and 3, steroid production by granulosa cells reached the maximal level during $24 \mathrm{hr}$ culture. In the preliminary RT-PCR study, a significant increase in mRNA expression of steroidogenesis related enzymes or proteins was observed by $0.1 \mathrm{IU} / \mathrm{ml}$ FSH and $5 \times 10^{5}$ theca cells under these experimental conditions (data not shown). Thus, further real-time RT-PCR assays were done using granulosa cells cultured with and without $0.1 \mathrm{IU} / \mathrm{ml} \mathrm{FSH}$ or $5 \times 10^{5}$ theca cells in serumfree medium for $24 \mathrm{hr}$.

Figure $4 \mathrm{~A}$ and $\mathrm{B}$ show that FSH significantly enhanced the mRNA levels for aromatase, P450scc, LHr, and StAR $(P<0.05)$, but not of $3 \beta$-HSD in granulosa cells. Theca cells also significantly increased aromatase mRNA expression $(P<0.05)$, while they did not alter P450scc, $3 \beta$-HSD, LHr, and StAR mRNA contents.

\section{DISCUSSION}

It is thought that, in vivo, FSH induces estrogen production by the granulosa cells of healthy antral follicles during the follicular phase. In the present in vitro study, recombinant human FSH enhanced aromatase mRNA expression in granulosa cells, but did not alter estradiol production. Our results are similar to those of previous studies that report that recombinant human FSH (Couzinet et al., 1988) or highly purified urinary FSH (Shoham et al., 1991) preparations were insufficient to induce optimal estradiol production in women with hypogonadotropic 


\section{Estradiol}
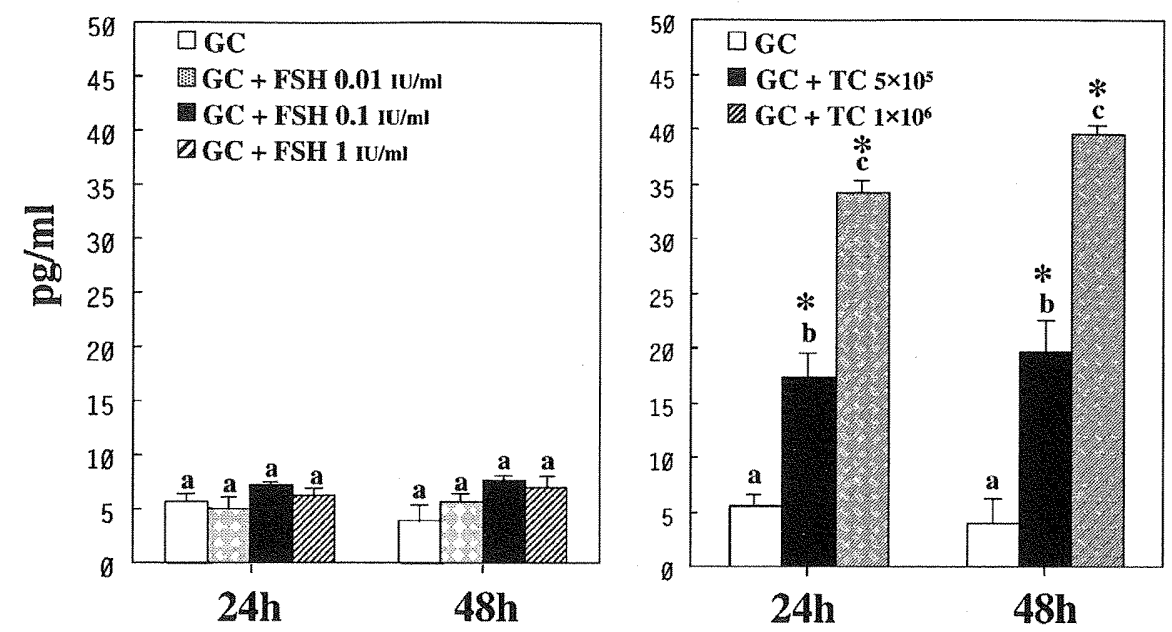

Fig. 2. Effect of FSH or theca cells on estrogen production by granulosa cells. Granulosa cells $\left(1 \times 10^{6}\right.$ viable cells per dish) were cultured $(48 \mathrm{hr})$ with and without FSH $(0.01-1 \mathrm{IU} / \mathrm{ml})$ or theca cells $\left(5 \times 10^{5}\right.$ or $1 \times 10^{6}$ viable cells per dish) in serum-free medium, and the concentrations of estradiol in the culture media were measured by RIA. Data are the mean + SEM of three different experiments with three replicate culture dishes. ${ }^{*} P<0.05$ versus GC.

hypogonadism, and that pure FSH stimulated growth of medium follicles but failed to increase serum estradiol concentrations in gonadotropin-releasing hormone immunized heifers (Crowe et al., 2001). We also demonstrated that FSH enhanced mRNA expression for P450scc, LHr, and StAR in granulosa cells, results in an increase in progesterone production. However, in vivo, progesterone production stimulated by FSH is not detected until the periovulatory period. These results suggest that although FSH promotes granulosa cell differentiation of early antral follicles in vitro, the stimulation of steroidogenesis by FSH may lead to the production of progesterone (i.e., premature luteinization), but not of estrogen.

\section{Progesterone}
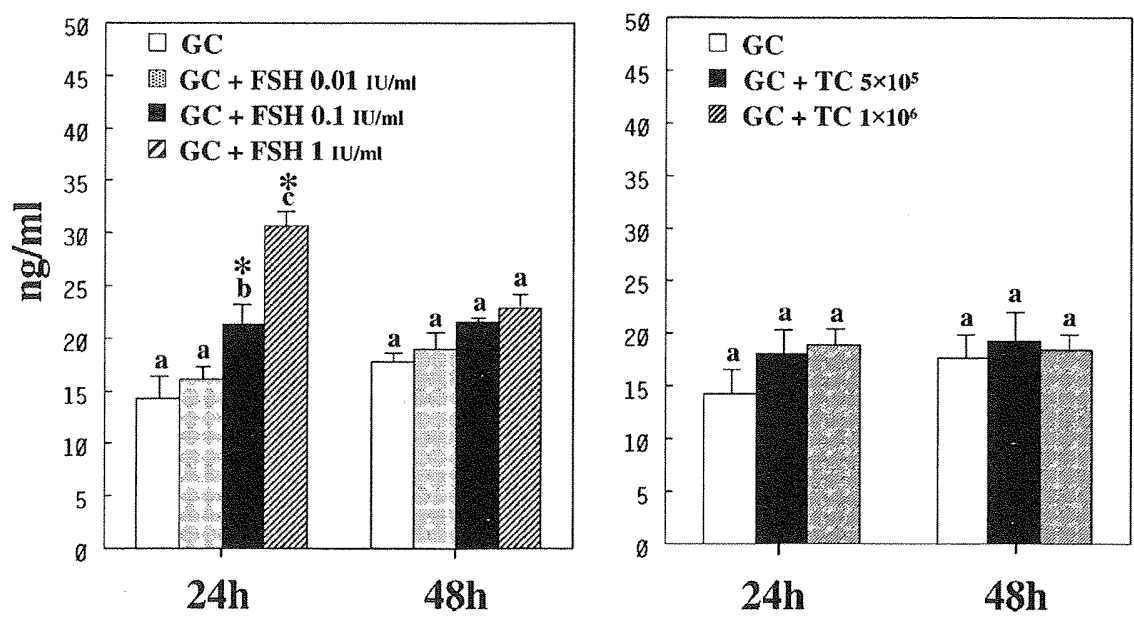

Fig. 3. Effect of FSH or theca cells on progesterone production by granulosa cells. Granulosa cells $\left(1 \times 10^{6}\right.$ viable cells per dish) were cultured $(48 \mathrm{hr})$ with and without $\mathrm{FSH}(0.01-1 \mathrm{IU} / \mathrm{ml})$ or theca cells $\left(5 \times 10^{5}\right.$ or $1 \times 10^{6}$ viable cells per dish) in serum-free medium, and the concentrations of progesterone in the culture media were measured by RIA. Data are the mean \pm SEM of three different experiments with three replicate culture dishes. ${ }^{*} P<0.05$ versus GC. 
A

aromatase (35)

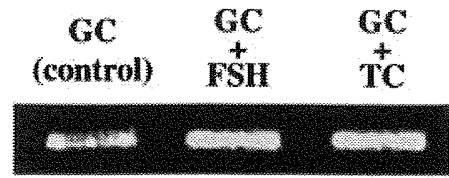

P450sce (25)

$30-1 \mathrm{HD}$ (25)

LH receptor (35)

StAR (35)

$36 \mathrm{~B} 4(25)$
In contrast, theca cells enhanced aromatase mRNA expression and increased estradiol production in granulosa cells. On the other hand, theca cells did not alter progesterone production and mRNA expression for P450scc, 3 $\beta$-HSD, LHr, and StAR in the granulosa cells. Accordingly, theca cells must be involved in regulating the granulosa cell differentiation at early antral follicles. Our results suggest that theca cells differentially regulate estradiol and progesterone production by granulosa cells in a way that reflects steroidogenesis during the follicular phase of the normal estrous cycle.

What is the physiological significance of these theca cell activities? In cattle, follicular recruitment is considered to be gonadotropin-dependent and occurs when antral follicles grow larger than $4 \mathrm{~mm}$ in diameter (Ginther et al., 1996; Webb et al., 1999). However, the mechanisms by which recruitable follicles $(<4 \mathrm{~mm}$ in diameter) grow to the recruitment stage $(4 \mathrm{~mm}$ in diameter) and shift to FSH dependent development, remains unknown. In the present study, theca cells, but not FSH, enhanced aromatase mRNA expression and estradiol production in granulosa cells of the recruitable follicle. Richards (1980) reported that estradiol enhances granulosa cell responsiveness to FSH in rats. Segaloff et al. (1990) reported that estradiol is required for the induction of $\mathrm{LHr}$ on granulosa cells of rodents. Accordingly, locally produced estradiol may contribute in a coordinated manner to the intraovarian regulation of follicular development and seems to be essential for obtaining gonadotropin dependency. Therefore, we propose that theca cells promote granulosa cell responsiveness to FSH by enhancing the expression of aromatase mRNA and estradiol production in these cells, which, in turn, results in recruitable follicles becoming dependent on gonadotropins.

Numerous follicular factors, such as steroids, growth factors, cytokines, and extracellular matrix molecules have been shown to modulate follicular cells in a paracrine fashion, and responsiveness of the granulosa cells to these factors appears to differ with respect to species, developmental stage, and culture conditions (Gougeon, 1996; Driancourt et al., 2000; McGee and Hsueh, 2000; Nilsson and Skinner, 2001; Richards, 2001; Vitt and Hsueh, 2001; Monget et al., 2002). In our system, factors with relatively low molecular weight derived from the theca cells may play central roles

Fig, 4. Effect of FSH or theca cells on mRNA expression in oranulosa cells. Granulosa cells $\left(1 \times 10^{6}\right.$ viable cells per dish) were cultured $(24 \mathrm{hr})$ with and without FSH $(0.1 \mathrm{IU} / \mathrm{ml})$ or theca cells $\left(5 \times 10^{5}\right.$ viable cells per dish) under serum-free conditions. A: Conventional RT-PCR analyses for bovine aromatase, P450scc, 3 $\beta$-HSD, LHr, and StAR were performed on total RNAs from the granulosa cells. The PCR cycles used for each factor are shown in parenthesis. B: Real-time quantitative RT-PCR analyses were performed using an ABI PRISM 7700 sequence detection system instrument and software (PE Applied Biosystems). Each transcript level of target genes (aromatase, P450scc, 3 $\beta$-HSD, LHr, and StAR) was normalized on the basis of the level of transcripts for the constitutive housekeeping gene product 36B4. Data are expressed as relationship to control (untreated GC) and are presented the mean $\pm S E M$ of three different experiments. $* P<0.05$ versus GC. 
because only the materials less than $12.5 \mathrm{kDa}$ can pass through the collagen membrane.

It is known that several growth factors expressed in theca cells stimulate the aromatase expression and estradiol production in granulosa cells, including insulin-like growth factors (IGF-I and IGF-II) (Adashi et al., 1985; Erickson et al., 1989; Christman et al., 1991; Yong et al., 1992; Mason et al., 1993; Hynes et al., 1996; Zhou et al., 1997; Spicer and Chamberlain, 1998; Monget and Bondy, 2000), transforming growth factor beta (TGF- $\beta$ ) (Ying et al., 1986; Bendell and Dorrington, 1988), and bone morphogenetic protein-4 (BMP-4) and BMP-7 (Shimasaki et al., 1999; Lee et al., 2001). However, none of these growth factors can directly regulate aromatase expression nor estradiol production by itself, and what they do is to enhance FSH-induced aromatase expression and estradiol production. Thus, our results showing theca cells stimulate aromatase mRNA expression and estradiol production in granulose cells without FSH seem to be unique.

In the present study, although culture media were supplemented with $10^{-8} \mathrm{M}$ testosterone as an estrogen precursor beforehand, it is possible that an additional supply of androgen produced by theca cells plays an important role in stimulating aromatase expression and estradiol production in granulosa cells. Actually, in the preoptic area, testosterone has been shown to upregulate aromatase activity directly (Barthazart et al., 1990). The mechanisms of cell communication through the basement membrane are still unclear, and the factors involved in the granulosa-theca cell communication in the control of granulosa cell differentiation in our coculture system remains to be identified. Regardless, we speculate that intraovarian regulators interact in a complex manner in the control of granulosa cell differentiation during early follicular development.

\section{CONCLUSIONS}

We have examined the influence of granulosa-theca cell interaction on the differentiation of granulosa cells during the gonadotropin-independent phase, using our co-culture system in which granulosa and theca cells were cultured on opposite sides of the collagen membrane. The results of the present study indicate that theca cells are involved in both rate-limiting steps in estrogen production, i.e., androgen substrate production and aromatase regulation. These results also suggest that theca cell-derived factors regulate estradiol and progesterone production in a way that reflects steroidogenesis during early follicular growth. Our previous studies suggest that theca cell-derived factors promote granulosa cell proliferation with the aid of serum (Kotsuji et al., 1990; Kotsuji and Tominaga, 1994) and suppress granulosa cell apoptosis under serum-free conditions (Tajima et al., 2002) at early antral follicle. Taken together, it can be concluded that granulosatheca cell interaction is a major follicular constituent in the control of follicular growth, maturation, and atresia during the early stage of follicular development. Further investigation of the local cellular interactions are essential to better understand ovarian physiology, and shed new light on several reproductive problems such as poor response to gonadotropin stimulation, premature ovarian failure, and polycystic ovarian syndrome.

\section{ACKNOWLEDGMENTS}

We are thankful to Serono for providing recombinant human FSH (Gonal-F). We thank the Kanazawa Meat Inspection Office (Kanazawa, Japan) for allowing us to collect the bovine ovaries used in these experiments. We also thank Mikiko Misawa for excellent technical assistance.

\section{REFERENCES}

Adashi EY, Resnick CE, D'Ercole AJ, Svoboda ME, Van Wyk JJ. 1985. Insulin-like growth factors as intraovarian regulators of granulosa cell growth and function. Endocr Rev 6:400-420.

Awotwi EK, Keeney DS, Hard DL, Anderson LL. 1984. Effects of pulsatile infusion of luteinizing hormone-releasing hormone on luteinizing hormone secretion and ovarian function in hypophysial stalk-transected beef heifers. Biol Reprod 31:989-999.

Bao B, Garverick HA. 1998. Expression of steroidogenic enzyme and gonadotropin receptor genes in bovine follicles during ovarian follicular waves: A review. J Anim Sci 76:1903-1921.

Barthazart J, Foidart A, Hendrick JC. 1990. The induction by testosterone of aromatase activity in the preoptic area and activation of copulatory behavior. Physiol Behav 47:83-94.

Bendell JJ, Dorrington J. 1988. Rat thecal/interstitial cells secrete a transforming growth factor-beta-like factor that promotes growth and differentiation in rat granulosa cells. Endocrinology 123:941948.

Campbell BK, Scaramuzzi RJ, Webb R. 1995. Control of antral follicle development and selection in sheep and cattle. J Reprod Fertil Suppl 49:335-350.

Christman GM, Randolph JF, Jr., Peegel H, Menon KM. 1991. Differential responsiveness of luteinized human granulosa cells to gonadotropins and insulin-like growth factor I for induction of aromatase activity. Fertil Steril 55:1099-1105.

Couzinet B, Lestrat N, Brailly S, Forest M, Schaison G. 1988. Stimulation of ovarian follicular maturation with pure folliclestimulating hormone in women with gonadotropin deficiency. J Clin Endocrinol Metab 66:552-556.

Crowe MA, Kelly P, Driancourt MA, Boland MP, Roche JF. 2001. Effects of follicle-stimulating hormone with and without luteinizing hormone on serum hormone concentrations, follicle growth, and intrafollicular estradiol and aromatase activity in gonadotropinreleasing hormone-immunized heifers. Biol Reprod 64:368-374.

Driancourt MA, Reynaud K, Cortvrindt R, Smitz J. 2000. Roles of KIT and KIT LIGAND in ovarian function. Rev Reprod 5:143-152.

Erickson GF, Garzo VG, Magoffin DA. 1989. Insulin-like growth factorI regulates aromatase activity in human granulosa and granulosa luteal cells. J Clin Endocrinol Metab 69:716-724.

Fortune JE, Rivera GM, Evans AC, Turzillo AM. 2001. Differentiation of dominant versus subordinate follicles in cattle. Biol Reprod 65:648-654.

Ginther OJ, Wiltbank MC, Fricke PM, Gibbons JR, Kot K. 1996. Selection of the dominant follicle in cattle. Biol Reprod 55:11871194.

Gong JG, Campbell BK, Bramley TA, Gutierrez CG, Peters AR, Webb R. 1996. Suppression in the secretion of follicle-stimulating hormone and luteinizing hormone, and ovarian follicle development in heifers continuously infused with a gonadotropin-releasing hormone agonist. Biol Reprod 55:68-74.

Gougeon A. 1996. Regulation of ovarian follicular development in primates: Facts and hypotheses. Endocr Rev 17:121-155.

Hymes AC, Sreenan JM, Kane MT. 1996. Modulation of the effects of FSH, androstenedione, epidermal growth factor (EGF) and insulinlike growth factor I (IGF-I) on bovine granulosa cells by GCIF, a growth-inhibitory factor of low molecular mass from bovine follicular fluid. J Reprod Fertil 108:193-197. 
Ireland JJ, Murphee RL, Coulson PB. 1980. Accuracy of predicting stages of bovine estrous cycle by gross appearance of the corpus luteum. J Dairy Sci 63:155-160.

Kotsuji F, Tominaga T. 1994. The role of gramulosa and theca cell interactions in ovarian structure and function. Microsc Res Tech 27:97-107.

Kotsuji F, Kamitani N, Goto K, Tominaga T. 1990. Bovine theca and granulosa cell interactions modulate their growth, morphology, and function. Biol Reprod 43:726-732.

Lee WS, Otsuka F, Moore RK, Shimasaki S. 2001. Effect of bone morphogenetic protein-7 on folliculogenesis and ovulation in the rat. Biol Reprod 65:994-999.

Mason HD, Margara R, Winston RM, Seppala M, Koistinen R, Franks S. 1993. Insulin-like growth factor-I (IGF-I) inhibits production of IGF-binding protein-1 while stimulating estradiol secretion in granulosa cells from normal and polycystic human ovaries. J Clin Endocrinol Metab 76:1275-1279.

Mazerbourg S, Overgaard MT, Oxvig C, Christiansen M, Conover CA, Laurendeau I, Vidaud M, Tosser-Klopp G, Zapf J, Monget P. 2001. Pregnancy-associated plasma protein-A (PAPP-A) in ovine, bovine, porcine, and equine ovarian follicles: Involvement in IGF binding protein-4 proteolytic degradation and mRNA expression during follicular development. Endocrinology 142:52435253.

McGee EA, Hsueh AJ. 2000. Initial and cyclic recruitment of ovarian follicles. Endocr Rev 21:200-214.

Monget P, Bondy C. 2000. Importance of the IGF system in early folliculogenesis. Mol Cell Endocrinol 163:89-93.

Monget P, Fabre S, Mulsant P, Lecerf F, Elsen JM, Mazerbourg S, Pisselet C, Monniaux D. 2002. Regulation of ovarian folliculogenesis by IGF and BMP system in domestic animals. Domest Anim Endocrinol 23:139-154.

Nilsson E, Skinner MK. 2001. Cellular interactions that control primordial follicle development and folliculogenesis. J Soc Gynecol Investig 8:S17-S20.

Richards JS. 1980. Maturation of ovarian follicles: Actions and interactions of pituitary and ovarian hormones on follicular cell differentiation. Physiol Rev 60:51-89.

Richards JS. 2001. Perspective: The ovarian follicle-A perspective in 2001. Endocrinology 142:2184-2193.

Segaloff DL, Wang HY, Richards JS. 1990. Hormonal regulation of luteinizing hormone/chorionic gonadotropin receptor mRNA in rat ovarian cells during follicular development and luteinization. Mol Endocrinol 4:1856-1865.

Shimasaki S, Zachow RJ, Li D, Kim H, Iemura S, Ueno N, Sampath K, Chang RJ, Erickson GF. 1999. A functional bone morphogenetic protein system in the ovary. Proc Natl Acad Sci USA 96:7282-7287.

Shoham Z, Balen A, Patel A, Jacobs HS. 1991. Results of ovulation induction using human menopausal gonadotropin or purified folliclestimulating hormone in hypogonadotropic hypogonadism patients. Fertil Steril 56:1048-1053.

Spicer LJ, Chamberlain CS. 1998. Influence of cortisol on insulin- and insulin-like growth factor 1 (IGF-1)-induced steroid production and on IGF-1 receptors in cultured bovine granulosa cells and thecal cells. Endocrine 9:153-161.

Tajima K, Orisaka M, Hosokawa K, Amsterdam A, Kotsuji F. 2002. Effects of ovarian theca cells on apoptosis and proliferation of granulosa cells: Changes during bovine follicular maturation. Biol Reprod 66:1635-1639.

Tilly JL, Kowalski KI, Schomberg DW, Hsueh AJ. 1992. Apoptosis in atretic ovarian follicles is associated with selective decreases in messenger ribonucleic acid transcripts for gonadotropin receptors and cytochrome P450 aromatase. Endocrinology 131:1670-1676.

Vitt UA, Hsueh AJ. 2001. Stage-dependent role of growth differentiation factor-9 in ovarian follicle development. Mol Cell Endocrinol 183:171-177.

Webb R, Campbell BK, Garverick HA, Gong JG, Gutierrez CG, Armstrong DG. 1999. Molecular mechanisms regulating follicular recruitment and selection. J Reprod Fertil Suppl 54:33-48.

Yada H, Hosokawa K, Tajima K, Hasegawa Y, Kotsuji F. 1999. Role of ovarian theca and granulosa cell interaction in hormone production and cell growth during the bovine follicular maturation process. Biol Reprod 61:1480-1486.

Ying SY, Becker A, Ling N, Ueno N, Guillemin R. 1986. Inhibin and beta type transforming growth factor (TGF beta) have opposite modulating effects on the follicle stimulating hormone (FSH) induced aromatase activity of cultured rat granulosa cells. Biochem Biophys Res Commun 136:969-975.

Yong EL, Baird DT, Yates R, Reichert LE, Jr., Hillier SG. 1992 Hormonal regulation of the growth and steroidogenic function of human granulosa cells. J Clin Endocrinol Metab 74:842-849.

Zhou J, Kumar TR, Matzuk MM, Bondy C. 1997. Insulin-like growth factor I regulates gonadotropin responsiveness in the murine ovary. Mol Endocrinol 11:1924-1933. 